\title{
Effect of Age and Number of Seedling per Hill on Growth and Yield of Black Scented Rice (Oryza sativa L.) Variety 'Chakhao Poireiton' under Manipur Condition
}

\section{K. Nandini Devi ${ }^{*}$, Ganesh Narayan ${ }^{1}$, K. Khamba Singh ${ }^{2}$, M. Anandi Devi², Herojit Singh Athokpam ${ }^{3}$ and A. Dorendro Singh ${ }^{4}$}

\author{
${ }^{1}$ Department of Agronomy, College of Agriculture, Central Agricultural University, \\ Imphal-795004, India \\ ${ }^{2}$ Department of Biochemistry, Manipur College, Imphal-795008, India \\ ${ }^{3}$ Department of Soil Science and Agricultural Chemistry, College of Agriculture, Central \\ Agricultural University, Imphal-795004, India \\ ${ }^{4}$ Department of Botany, Mayai Lambi College, Yumnam Huidrom, Imphal West, Manipur- \\ 795009, India
}

*Corresponding author

\begin{tabular}{|l|}
\hline Ke y w o r d s \\
Growth, Rice, \\
$\begin{array}{l}\text { Seedling age, } \\
\text { Seedling per hill, } \\
\text { Yield }\end{array}$ \\
\hline Article Info \\
\hline $\begin{array}{l}\text { Accepted: } \\
\text { 15 June } 2019 \\
\text { Available Online: } \\
\text { 10 July } 2019\end{array}$ \\
\hline
\end{tabular}

A B S T R A C T
Field experiments were conducted during kharif 2014 and 2015 to study the effect of age and number of seedling per hill on growth and yield of black scented rice (Oryza sativa L.) variety 'Chakhao Poireiton' under Manipur condition to find out the suitable age of seedling and number of seedling per hill. The experiment consists of four seedling age viz., $A_{1}-15$ days old seedling; $A_{2^{-}} 25$ days old seedling; $A_{3}-35$ days old seedling; $A_{4}-45$ days old seedling and four number of seedlings per hill viz., $S_{1}-1$ seedling/hill; $S_{2}-2$ seedling/hill; $\mathrm{S}_{3}-3$ seedling/hill; $\mathrm{S}_{4}-4$ seedling/hill. The highest plant height $(193.67 \mathrm{~cm})$ was recorded from the transplanting of 15 day old seedling and decreases with the increase in seedling age. Transplanting of 15 day old seedling produced maximum yield attributes like numbers of effective tillers per hill (11.00), length of panicle $(25.73 \mathrm{~cm})$, grain yield (1946 kg/ha) and straw yield (3473 kg/ha). Among the different number of seedling/hill, maximum plant height $(197.28 \mathrm{~cm})$ was observed from the transplanting of 4 seedlings/hill followed by 2 seedling/hill $(193.47 \mathrm{~cm})$. As the maximum length of panicle $(24.99 \mathrm{~cm})$ was observed in 1 seedling /hill thus showed superiority over the rest of the number of seedling per hill. The highest grain yield $(1719 \mathrm{~kg} / \mathrm{ha})$ recorded in the $\mathrm{S}_{3}(3$ seedlings per hill) was also significantly higher than the other treatments and the lowest grain yield (1346 kg/ha) in $S_{1}$ (1 seedling per hill). Highest gross return (Rs 1,08,945/ha), net return (Rs 69,536/ha) and B:C ratio (1.76) were obtained from the treatment $\mathrm{A}_{1} \mathrm{~S}_{2}$ (transplanting of 15 days old seedling with 2 seedlings/hill). The total anthocyanin content in Chakhao Poireiton was found to be in the range of 599 to $724 \mathrm{mg} / \mathrm{kg}$ cyaniding 3 -glucoside $/ \mathrm{kg}$ of powdered rice. The anthocyanin content decreases as the increase in seedling age. 


\section{Introduction}

Rice is the most important cereal food crop of the world providing major source of the food energy for more than half of the population. Rice is grown in 114 countries across the world on an area about 158.3 million hectares with annual production of over 685.24 million tonnes (FAI, 2011). India needs to increase the production by at least 2.5 million tonnes of milled rice every year to sustain the level of self-sufficiency and export, utilizing the same or even educed natural resources like land, water, labour and without deteriorating the fragile ecosystem (Anonymous, 2006). Rice occupies a most important place in Indian agriculture and it is contributes to 15 per cent of annual GDP and provides 43 per cent calorie requirement for more than 70 per cent of Indians. In India, it is cultivated on an area of 41.9 million hectares which is maximum among all rice growing countries, annual production of about 133.7 million tonnes with productivity of 3.2 tonnes per hectare (FAI, 2011). In the absence of modern technologies, farmers of the North-eastern region relied heavily on traditional knowledge systems for managing rice based systems for centuries. Adoption of optimum production technology along with resource conservation practices will enhance rice productivity in the region.

The black scented rice of Manipur cultivar 'Chakhao poireiton' is considered to be both food and medicine. The black colour of Manipur rice is due to the presence of anthocyanin, which act as a powerful antioxidant. It is well known that rice consists of anthocyanin, cellulose, lignin, vitamin B, amino acid, and some minerals (Ryan et al., 2011). Anthocyanin's are the most important water-soluble pigments that belong to the flavonoid group and are accountable for the different colour in plant tissues (Trouillas et al., 2016; Cortez et al., 2017). The consumption of coloured rice varieties is increasing among the people, because of its health benefits. As per the Japan Health Food and Nutrition Food Association, $29 \mathrm{mg}$ of anthocyanin per day is the recommended dose for human consumption (Yamamoto et al., 2013). The price of scented rice is also very high in global market in comparison to normal rice. The yield can be enhanced by adopting new agronomic practices according to the crop and their climatic requirement. Keeping the above points in view the experiment entitled "Effect of age and number of seedling per hill on growth and yield of black scented rice (Oryza sativa L.) variety 'Chakhao Poireiton' under Manipur condition" was undertaken during kharif 2014 and 2015 at Research farm College of Agriculture, Central Agricultural University, Imphal with the objective to find out the suitable age of seedling and number of seedling per hill.

\section{Materials and Methods}

The soil of the experimental site was clay with $\mathrm{pH}$ 5.6, organic carbon (1.19\%), available nitrogen $(440 \mathrm{~kg} / \mathrm{ha})$, available $\mathrm{P}_{2} \mathrm{O}_{5}(17)$ and available $\mathrm{K}_{2} \mathrm{O}(313 \mathrm{~kg} / \mathrm{ha})$. The experiment consists of four seedling age viz., $\mathrm{A}_{1}-15$ days old seedling; $A_{2}-25$ days old seedling; $A_{3}-35$ days old seedling; $A_{4}-45$ days old seedling and four number of seedlings per hill viz., $S_{1}-$ 1 seedling/hill; $S_{2}-2$ seedling/hill; $S_{3}-3$ seedling/hill; $\quad \mathrm{S}_{4}-4$ seedling/hill. The experiment was laid out in factorial randomised block design with three replications. The recommended dose of $\mathrm{N}$ : $\mathrm{P}$ : $\mathrm{K}$ was $60: 40: 30 \mathrm{~kg} / \mathrm{ha}$. The fertilizers were used in the form of urea, single super phosphate and muriate of potash. Full dose of phosphorous and potash along with half dose of urea were applied uniformly applied as a basal to all the plots one day before transplanting. The remaining half dose of nitrogen was applied in two equal splits at active tillering stage (25 DAT) and panicle initiation stages (55 DAT). The transplanting 
was done during June to July and harvested in November in both the years. The data obtained from the experiment were statistically analysed, adopting the procedure of analysis of variance wherever variance ratio is significant, critical difference is reported at 5 $\%$ level of probability.

Soil samples were collected, dried and ground for chemical analysis. Soil $\mathrm{pH}$ was determined by using a glass electrode $\mathrm{pH}$ meter (Jackson, 1973) and organic carbon by wet oxidation method (Walkley and Black, 1935). The available $\mathrm{N}$ of the soil was determined by Kjeldahl method (Jackson, 1973), available P by ascorbic acid and blue colour method (Watanabe and Olsen, 1965) and available K by flame photometer (Jackson, 1973).

Total anthocyanin content was determined by the methods of Giusti et al., (1999). In short, black rice extracts were separately diluted with $0.4 \mathrm{M}$ sodium acetate buffer $(\mathrm{pH} 4.5)$ and $0.025 \mathrm{M}$ potassium chloride solution ( $\mathrm{pH} 1.0)$, and the absorbance values of both dilutions were measured at 700 and $510 \mathrm{~nm}$. The results were expressed as milligrams of anthocyanin (cyanidin 3 glucoside, C3G) equivalent per kilogram of dry weight of the extract. Calculations were performed with the equation $\mathrm{A}=[(\mathrm{A} 510-\mathrm{A} 700$ at $\mathrm{pH} 1.0)$ (A510-A700 at $\mathrm{pH}$ 4.5)] with a molar extinction coefficient of 26,900 and a molecular weight of $449.2 \mathrm{~g} / \mathrm{mol}$.

\section{Results and Discussion}

\section{Effect of age of seedling on growth, yield attributes and yield}

The highest plant height $(193.67 \mathrm{~cm})$ was recorded from the transplanting of 15 day old seedling and decreases with the increase in seedling age. It was found to be significantly higher than the rest of other treatment. The taller plant in early planting might be due to availability of more time for growth period with optimum photoperiod and temperature for the growth of the crop plants which may result in more nitrogen absorption for the synthesis of protoplasm responsible for rapid cell division which may increase the plant in shape and size. Similar finding were also reported by Naidu et al., (2013) and Nayak et al., (2003). Increase in plant height by transplanting 14 days old seedlings was also observed by Gokila (2005) and Sivakumar (2006). The age of seedling had significant effect on number of effective tillers per hill. The highest numbers of effective tillers per hill was recorded (11.00) when transplanted 15 days old seedling and the lowest (10.37) when transplanted 45 days old seedling. As the age of seedling increased, the numbers of effective tillers were decreased. This finding is in conformity with the findings of Ali et al., (2013).

The transplanted 15 days old seedling gives significantly higher length of panicle $(25.73$ $\mathrm{cm})$ than the other treatments and lowest $(22.53 \mathrm{~cm})$ from transplanted with 45 days old seedling. Further, with transplanting more aged seedling there was gradual decrease in length of panicle. The longest panicle produced by early planting might be due to availability of more time for better development of plant parts which may result in the better development of yield attributing characters. Similar results have been reported by Singh et al., (2004). The effect of different age of seedling had no significant effect on the thousand grains weight.

The maximum grain yield (1946 kg/ha) recorded from $A_{1}$ (15 days old seedling) was found significantly higher than the rest treatments whereas the lowest grain yield (1226 kg/ha) in $\mathrm{A}_{4}$ (45 days old seedlings). There was linear decrease in grain yield with increase in age of seedling. This is in confirmed by Ali et al., (2013). The younger 
seedlings establishes quickly in the main field and start growing at a faster rate compared to conventional seedlings which remain in nursery bed competition with one another for 4-5 weeks before transplanting. Transplanting more aged seedling results in lower rice yield because older seedlings suffer from stem and root injury during pulling. Rajendran et al., (2004) found that transplanting 15 days old seedlings gave higher yield than rice crop planted with 25 days old seedlings. Similar trend was also observed in straw yield. The highest straw yield $(3473 \mathrm{~kg} / \mathrm{ha})$ recorded from $\mathrm{A}_{1}$ (15 days old seedling) was significantly higher than the other treatment and lowest straw yield (1885 kg/ha) in $\mathrm{A}_{4}(45$ days old seedling).

Effect of number of seedling /hill on growth, yield attributes and yield

The number of seedlings per hill markedly influenced the plant height of rice. Among the different number of seedling/hill, maximum plant height $(197.28 \mathrm{~cm})$ was observed from the transplanting of 4 seedlings/hill followed by 2 seedling/hill $(193.47 \mathrm{~cm})$ and the lowest $(187.41 \mathrm{~cm})$ from the transplanting of 1 seedling/hill. The number of seedling per hill increases the plant height as we increase the seedling per hill but not at an increasing rate. The higher plant height in 4seedlings/hill might be due to exposure of large number of plants and leaf area to sunlight during the growth period resulting in better photosynthesis and consequently resulting in higher plant height. The highest number of effective tillers per hill (11.82) recorded in $\mathrm{S}_{4}$ (4 seedlings/hill) was significantly higher than the other treatments whereas the lowest (8.90) in transplanting 1 seedling/hill. This is in conformity with the findings of Verma et al., (2002). The interaction effect between the age of seedling and the number of seedling per hill on number of effective tillers also had a significant effect. Transplanting with 1 seedling/hill gave significantly higher panicle length $(24.99 \mathrm{~cm})$ than the others whereas the lowest $(23.73 \mathrm{~cm})$ from transplanting of 4seedlings/hill. As the maximum length of panicle was observed in 1 seedling /hill thus showed superiority over the rest of the number of seedling per hill. The interaction effect of between the age and number of seedling per hill had significant effect on the length of panicle. The different number of seedling per hill also had significant effect on length of panicle. Thousand grains weight was not influenced significantly by the age and number of seedling per hill (Table 1).

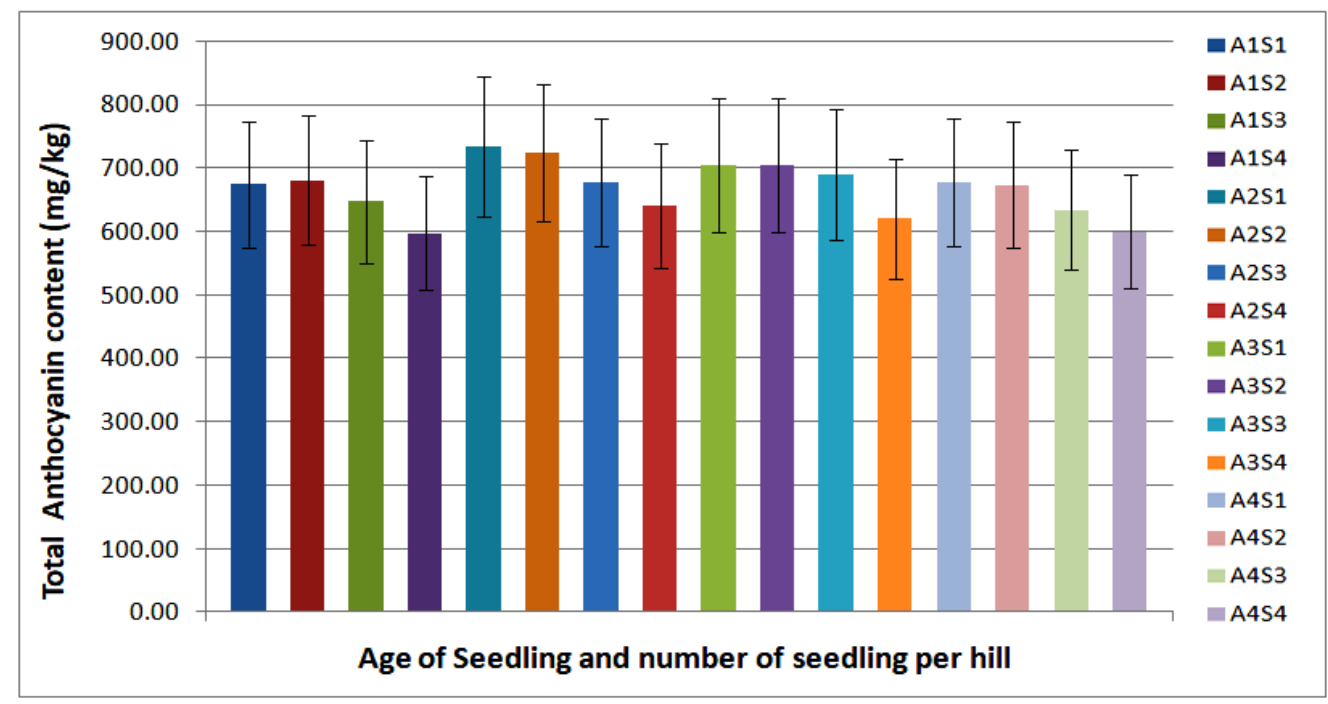


Table.1 Effect of seedling age and number of seedling per hill on growth and yield of black scented rice variety 'Chakhao Poireiton' (average for two years)

\begin{tabular}{|c|c|c|c|c|c|c|}
\hline Treatment & $\begin{array}{l}\text { Plant height } \\
\text { (cm) }\end{array}$ & $\begin{array}{l}\text { No. of } \\
\text { Effective } \\
\text { tillers/hill }\end{array}$ & $\begin{array}{c}\text { Panicle } \\
\text { length } \\
(\mathrm{cm})\end{array}$ & $\begin{array}{c}\text { Test weight } \\
\text { (g) }\end{array}$ & $\begin{array}{c}\text { Grain yield } \\
\text { (kg/ha) }\end{array}$ & $\begin{array}{c}\text { Straw yield } \\
(\mathrm{kg} / \mathrm{ha})\end{array}$ \\
\hline \multicolumn{7}{|l|}{ Seedling age (A) } \\
\hline $\mathbf{A}_{1}$ & 193.67 & 10.87 & 25.73 & 29.13 & 1946 & 3473 \\
\hline $\mathbf{A}_{2}$ & 192.79 & 10.73 & 24.83 & 28.96 & 1762 & 2952 \\
\hline $\mathbf{A}_{3}$ & 191.45 & 10.68 & 24.75 & 28.90 & 1329 & 2401 \\
\hline $\mathbf{A}_{4}$ & 190.07 & 10.37 & 22.53 & 28.51 & 1226 & 1885 \\
\hline S.Em. $( \pm)$ & 0.16 & 0.02 & 0.11 & 0.11 & 14.10 & 21.00 \\
\hline C.D. $(P=0.05)$ & 0.46 & 0.07 & 0.32 & N S & 40.72 & 60.65 \\
\hline \multicolumn{7}{|c|}{ Number of Seedling/hill (S) } \\
\hline $\mathbf{S}_{1}$ & 187.41 & 8.90 & 24.99 & 28.60 & 1346 & 2283 \\
\hline $\mathbf{S}_{\mathbf{2}}$ & 193.47 & 10.43 & 24.87 & 28.29 & 1704 & 2412 \\
\hline $\mathbf{S}_{3}$ & 189.23 & 11.82 & 24.25 & 27.18 & 1719 & 2947 \\
\hline $\mathbf{S}_{4}$ & 197.28 & 11.50 & 23.73 & 26.77 & 1494 & 3069 \\
\hline S.Em. $( \pm)$ & 0.16 & 0.02 & 0.11 & 0.11 & 14.10 & 21.00 \\
\hline C.D. $(P=0.05)$ & 0.46 & 0.07 & 0.32 & N S & 40.72 & 60.65 \\
\hline \multicolumn{7}{|l|}{ Interaction $(\mathrm{A} \times \mathrm{S})$} \\
\hline S.Em. $( \pm)$ & 0.32 & 0.05 & 0.22 & 0.21 & 28.20 & 42.00 \\
\hline C.D. $(P=0.05)$ & 0.93 & 0.14 & 0.64 & $\mathrm{NS}$ & 81.44 & 121.30 \\
\hline
\end{tabular}

$A_{1}=15$ days old seedling; $A_{2}=25$ days old seedling; $A_{3}=35$ days old seedling; $A_{4}=45$ days old seedling; $S_{1}=1$ seedling/hill; $S_{2}=2$ seedling/hill; $S_{3}=3$ seedling/hill; $S_{4}=4$ seedling/hill

Table.2 Effect of seedling age and number of seedling per hill on economics of black scented rice variety 'Chakhao Poireiton' (average for two years)

\begin{tabular}{|l|c|c|c|c|}
\hline Treatments & $\begin{array}{c}\text { Total cost of the cultivation per } \\
\text { hectare (Rs/ha) }\end{array}$ & $\begin{array}{c}\text { Gross return } \\
\text { (Rs/ha) }\end{array}$ & $\begin{array}{c}\text { Net return } \\
\text { (Rs/ha) }\end{array}$ & B:C ratio \\
\hline $\mathbf{A}_{\mathbf{1}} \mathbf{S}_{\mathbf{1}}$ & 38209 & 78115 & 39906 & 1.04 \\
\hline $\mathbf{A}_{\mathbf{1}} \mathbf{S}_{\mathbf{2}}$ & 39409 & 108945 & 69536 & 1.76 \\
\hline $\mathbf{A}_{\mathbf{1}} \mathbf{S}_{\mathbf{3}}$ & 40009 & 97320 & 57311 & 1.43 \\
\hline $\mathbf{A}_{\mathbf{1}} \mathbf{S}_{\mathbf{4}}$ & 40609 & 96400 & 55791 & 1.37 \\
\hline $\mathbf{A}_{\mathbf{2}} \mathbf{S}_{\mathbf{1}}$ & 38209 & 75450 & 37241 & 0.97 \\
\hline $\mathbf{A}_{\mathbf{2}} \mathbf{S}_{\mathbf{2}}$ & 39409 & 87040 & 47631 & 1.21 \\
\hline $\mathbf{A}_{\mathbf{2}} \mathbf{S}_{\mathbf{3}}$ & 40009 & 95905 & 55896 & 1.40 \\
\hline $\mathbf{A}_{\mathbf{2}} \mathbf{S}_{\mathbf{4}}$ & 40609 & 82445 & 41836 & 1.03 \\
\hline $\mathbf{A}_{\mathbf{3}} \mathbf{S}_{\mathbf{1}}$ & 38209 & 45660 & 7451 & 0.20 \\
\hline $\mathbf{A}_{\mathbf{3}} \mathbf{S}_{\mathbf{2}}$ & 39409 & 60965 & 21556 & 0.55 \\
\hline $\mathbf{A}_{\mathbf{3}} \mathbf{S}_{\mathbf{3}}$ & 40009 & 76595 & 36586 & 0.91 \\
\hline $\mathbf{A}_{\mathbf{3}} \mathbf{S}_{\mathbf{4}}$ & 40609 & 67170 & 26561 & 0.65 \\
\hline $\mathbf{A}_{\mathbf{4}} \mathbf{S}_{\mathbf{1}}$ & 38209 & 61530 & 23321 & 0.61 \\
\hline $\mathbf{A}_{\mathbf{4}} \mathbf{S}_{\mathbf{2}}$ & 39409 & 63950 & 24541 & 0.62 \\
\hline $\mathbf{A}_{\mathbf{4}} \mathbf{S}_{\mathbf{3}}$ & 40009 & 64350 & 24341 & 0.61 \\
\hline $\mathbf{A}_{\mathbf{4}} \mathbf{S}_{\mathbf{4}}$ & 40609 & 54525 & 13916 & 0.34 \\
\hline $\mathbf{A}_{\mathbf{1 5}}$ & $\mathbf{A}$ & $\mathbf{4}$ & & \\
\hline
\end{tabular}

$A_{1}=15$ days old seedling; $A_{2}=25$ days old seedling; $A_{3}=35$ days old seedling; $A_{4}=45$ days old seedling; $S_{1}=1$ seedling/hill; $S_{2}=2$ seedling/hill; $S_{3}=3$ seedling/hill; $S_{4}=4$ seedling/hill 
The highest grain yield (1719 kg/ha) recorded in the $\mathrm{S}_{3}$ (3 seedlings per hill) was also significantly higher than the other treatments and the lowest grain yield (1346 kg/ha) in $S_{1}$ (1 seedling per hill). The interaction effect of age of seedling and number of seedling per hill also had significant effect on the grain yield of rice. Anitha (2005) found that planting of single seedling/ hill in straight rows both ways, alternate wetting and drying, early and frequent weeding using a mechanical weeder encouraged the proliferation of microorganisms that symbiotically enhanced the plant capability to produce more tillers, with vigorous and healthy root growth, and a larger number of panicles heavily laden with grains. Two seedlings/ hill was the best treatment to get the highest yield per unit area. It might be due to the highest panicle length, number of fertile spikelets/ panicle and 1000 grain yield and lowest number of sterile spikelets/ panicle (Alam et al., 2012). Similar results were also obtained by Islam et al., (2002). The different number of seedling per hill also had significant effect on the yield of straw. The maximum yield of straw (3069 kg/ha) was observed in $\mathrm{S}_{4}$ (4 seedlings per hill) and the lowest $(2283 \mathrm{~kg} / \mathrm{ha})$ from in $\mathrm{S}_{1}(1$ seedling per hill). Interaction effect of the different levels of the age of seedling and number of seedling per hill also had significant effect on the production of straw yield of rice crop.

\section{Economics}

The treatment $\mathrm{A}_{1} \mathrm{~S}_{4}$ (15 days old seedling and 4 seedlings per hill) showed the highest cost of production (Rs 40,609/ha) of Manipur black scented rice and the lowest (Rs $38,206 /$ ha) from the treatment $\mathrm{A}_{1} \mathrm{~S}_{1}$ (15 days old seedling and 1 seedling per hill). Table 2 indicated the highest gross return (Rs. 1,08,945/ha), net return (Rs 69,536/ha) and $\mathrm{B}: \mathrm{C}$ ratio (1.76) from the treatment $\mathrm{A}_{1} \mathrm{~S}_{2}$ (transplanting of 15 days old seedling with 2 seedlings/hill) whereas the lowest gross return (Rs 45,660/ha), net return (Rs 7451/ha) and $\mathrm{B}: \mathrm{C}$ ratio (0.20) from the treatment $\mathrm{A}_{3} \mathrm{~S}_{1}$ (transplanting of 35 day old seedling with 1 seedling/hill). Transplanting 14 days old seedlings from modified mat nursery in zigzag pattern $(25 \times 25 \mathrm{~cm})$ recorded higher net return (Rs.38036/ ha) and B: C ratio (2.6) (Veeramani, 2007). The combination of young seedlings, single seedling, square planting and cono weeding registered the highest net return (Rs.12,574/ha) and B:C ratio (1.87) compared to normal practice (Chellamuthu and Sridevi, 2006).

\section{Total anthocyanin content}

In the present study, anthocyanins were extracted from black scented rice using acidified methanol (Soxhlet). The total anthocyanin content in Chakhao Poireiton was found to be in the range of 599 to 724 $\mathrm{mg} / \mathrm{kg}$ cyaniding 3-glucoside/kg of powdered rice. The anthocyanin content decreases as the increase in seedling age.

From the above investigation it can be concluded that transplanting of 15 days old seedling with 2 seedlings/hill was found to be best for obtaining maximum income.

\section{Acknowledgement}

The authors are thankful to the Dean, College of Agriculture, Central Agricultural University, Imphal for financial and technical support to carry out this research experiment.

\section{References}

Alam, M. S.; Baki, M. A.; Sultana, M.S.; Ali, K. J.; and Islam, M. S. (2012). Effect of variety, spacing and number of seedlings per hill on the yield potentials of Transplant Aman rice. Int. J. Agr. \& Agri. R., 2(12): 10-15. 
Alam, M.S., Baki, M.I., Sultana, M.S., Ali, K.J. and Slam, M.S. (2012). Effect of variety, spacing and number of seedlings per hill on the yield potentials of transplant aman rice. Int. J. Agron. and Agril. Res., 2(12): 10-15.

Ali, M.S., Hasan, M.A., Sikder, S., Islam, M.R. and Hafiz, M.H.R. (2013). Effect of seedling age and water management on the performance of boro rice (Oryza sativa L.) variety BRRI Dhan 28. The Agriculturists, 11(2): 28-37.

Anitha, S. (2005). System of Rice intensification. Kissan World, pp. 41.

Chellamuthu, V. and Sridevi, V. (2006). Relative contribution of different components of System of Rice Intensification (SRI) to the yield of rice (Oryza sativa L). In: Abstract, Second International Rice Congress, Pp. 477.

Cortez, R., Luna-Vital, D. A., Margulis, D. and Gonzalez de Mejia, E. (2017). Natural pigments: Stabilization methods of anthocyanins for food applications. Comprehensive Reviews in Food Science and Food Safety, 16(1): 180198.

FAI (2011). Fertilzer Statiatics, The fertilizer association of India, New Delhi.

Giusti, M.M., Rodri'guez-Saona, L.E. and Wrolstad, R.E. (1999). Molar absorptivity and color characteristics of acylated and non-acylated pelargonidinbased anthocyanins. J. Agric. Food Chem., 47: 4631-4637

Gokila, S. (2005). Evaluation of SRI techniques with varieties, vermicompost and time of $\mathrm{N}$ application in rice. M.Sc (Ag.) Thesis submitted to and approved by Tamil Nadu Agricultural University, Coimbatore, Tamil Nadu.

Islam M.M. (2002). Enhancement of growth and yield of Boro rice through modification of SRI technique in terms of fertilizer management, spacing and seedling age. M.S. Thesis, Bangladesh
Agricultural University, Mymensingh, 43-117.

Jackson, M. L. (1973). Soil chemical analysis. Published by Prentice- Hall of India Pvt. Limited, New Delhi, India pp. 111203.

Naidu, G.j., Rao, K.T., Rao, A.U. and Reddy, D.S. (2013). Age of seedling and planting pattern on grain yield, protein content, NPK uptake and postharvest nutrient status of rice under SRI. $J$. Acade. Indust. Res., Vol. 2: 334-337.

Nayak, B.C., Dalai, B.B. and Chodhury, B.K. (2003). Response of hybrid rice to date of planting, spacing and Seedling rate during wet season. Indian J. Agron., 48(3): 172-174.

Rajendran, R., Ravi, V., Nadanasabapathy, T., Valliappan, K., Ramanathan, S., Jayaraj, T. and Balasubramanian, V. (2004). Modified Mat Nursery for producing robust young seedlings in 15 days for early transplanting and enhanced productivity under transformed rice cultivation. Indian $J$. Agron., 49(2): 155-157.

Ryan, E. P., Heuberger, A. L., Weir, T. L., Barnett, B., Broeckling, C. D. and Prenni, J. E. (2011). Rice bran fermented with Saccharomyces boulardii generates novel metabolite profiles with bioactivity. Journal of Agricultural and Food Chemistry, 59(5): 1862-1870.

Singh, T.; Shivay, Y.S. and Singh, S. (2004). Effect of date of transplanting and nitrogen on productivity and nitrogen use indices in hybrid and non-hybrid aromatic rice. Acta Agronomica Hungarica, 52 (3): 245-252.

Sivakumar, S. (2006). Studies on rice rhizosphere chemistry under selected integrated crop management (ICM) practices in rice soils of Tamil Nadu. M.Sc. (Ag.)-Thesis submitted to and approved by Tamil Nadu Agricultural 
University, Coimbatore, Tamil Nadu. Trouillas, P., Sancho-García, J.C., De Freitas, V., Gierschner, J., Otyepka, M. and Dangles, O. (2016). Stabilizing and modulating color by copigmentation: Insights from theory and experiment. Chemical Reviews, 116(9): 4937-4982.

Veeramani, P. (2007). Effect of mat nursery management and planting pattern (using rolling markers) in system of rice intensification. M.Sc. (Ag.)-Thesis submitted to and approved by Tamil Nadu Agricultural University, Coimbatore, Tamil Nadu.

Verma, A.K., Pandey, N. and Tripathi, S. (2002). Effect of transplanting spacing and number of seedlings on productive tillers, Spikelet sterility, grain yield and harvest index of hybrid rice. IRRN, 27(1): 51.

Walkley, A. C. and Black T. A. (1935). Estimation of soil organic carbon by chromic acid titration method. Soil Sci., 47: 29-38.

Watanabe F.S. and Olsen S.R. (1965). Test of an ascorbic acid method for determining phosphorus in water and $\mathrm{NaHCO} 3$ extracts from soil. Soil Sci. Soc. Amer. Proc., 29:677-678.

Yamamoto, M., Yamaura, K., Ishiwatari, M. and Ueno, K. (2013). Difficulty for consumers in choosing commercial bilberry supplements by relying only on product label information. Pharmacognosy Research, 5(3): 212215.

\section{How to cite this article:}

Nandini Devi, K., Ganesh Narayan, K. Khamba Singh, M. Anandi Devi, Herojit Singh Athokpam and Dorendro Singh, A. 2019. Effect of Age and Number of Seedling per Hill on Growth and Yield of Black Scented Rice (Oryza sativa L.) Variety 'Chakhao Poireiton' under Manipur Condition. Int.J.Curr.Microbiol.App.Sci. 8(07): 1738-1745. doi: https://doi.org/10.20546/ijcmas.2019.807.206 